\title{
Analisis Hukum Pembentukan Badan Usaha Milik Desa dalam Upaya Meningkatkan Pendapatan Asli Desa di Kecamatan Babalan Kabupaten Langkat
}

\author{
Agus Adhari \\ Ismaidar \\ Faculty of Law, University of Pembangunan Panca Budi \\ adharyagus@gmail.com,ismaidarisma@yahoo.com \\ Submitted: 2017-10-07; Reviewed: 2017-11-07; Accepted: 2017-11-28
}

\begin{abstract}
The Act No. 6 of 2014 on Village, mandates the establishment of Village Owned Enterprise (BUMDES) as an effort to increase the Village Generated Revenue (PADes) for creating an independent village. This research begins by analyzing the BUMDES practice in each village within Babalan sub-district, and adjusting it to the regulation, so the problems in the management of BUMDES in each village within Babalan Sub-district (Langkat Regency) are found. The research method of this research is using qualitative research with empirical juridical approach. The result shows that the process of establishing BUMDES in each village within Babalan sub-district has not been running well. The establishment of BUMDES is done in haste due to the "order" of the legislation of BUMDES (Ministerial Regulation No. 4 of 2015). The establishment of BUMDES is more due to the existence of a command to equity capital to BUMDes, so, the form and business sector of BUMDes is determined without deliberation of all elements of the village community. Then the mechanism of equity is not according to the regulation. Usually, the manager of BUMDES has to do some presentation the proposal and proposes the required budget, but in practice, the budget amount is promised first by the headman even the proposal is not submitted yet by the BUMDES. Consequently, the BUMDES budget must be adjusted to the budget which promised by the Headman. Furthermore, BUMDES has not played a significant role in increasing the village generated revenue, this can be seen from Village Budget 2016 where BUMDES has not paid dividends.
\end{abstract}

Keywords: Village Owned Enterprise; Village Government; Village Generated Revenue

\section{PENDAHULUAN}

Bergesernya arah pembangunan yang semula dimulai dari daerah otonom tingkat kabupaten/kota yang dirasa tidak memberikan kemajuan signifikan terhadap pembangunan nasional, hal ini menjadi pertimbangan perlunya pengaturan ulang terkait visi dan misi pembangunan nasional. Menjawab permasalahan tersebut, diterbitkanlah Undang-Undang Nomor 6 Tahun 2014 tentang Desa, yang dimulainya babak baru pembangunan 
nasional dari satuan pemerintahan paling dekat dengan masyarakat yaitu Desa. ${ }^{1}$

Pemerintahan Desa yang secara struktural tetap berada di bawah Kabupaten/Kota tetap menjadi bagian pemerintahan daerah kabupaten/kota, namun pengelolaan terhadap Desa dilakukan secara mandiri, pemerintah daerah hanya sebagai pengawas dan pembina dalam mencapai tujuan pembangunan daerah melalui pemberdayaan Desa. Salah satu upaya pembangunan desa dimulai dengan pembangunan sumberdaya dan keuangan desa agar penyelenggaraan pemerintahan desa dapat terwujud secara mandiri.

Terkait pembangunan sumber daya dan keuangan desa, Undang-Undang Nomor 6 Tahun 2014 tentang Desa memberikan peluang pada Desa untuk dapat membangun Desa dengan mendirikan Badan Usaha Milik Desa (BUMDes), hal ini bertujuan agar desa dapat menjadi bagian dari proses pembangunan nasional. ${ }^{2}$ Layaknya satuan pemerintahan dari pusat yang dapat mendirikan Badan Usaha Milik Negara (BUMN) dan Pemerintah daerah, Provinsi dan Kabupaten/Kota yang dapat mendirikan Badan Usaha Milik Daerah (BUMD), hal demikian juga diharapkan pada Desa dengan membangun BUMDes

\footnotetext{
${ }^{1}$ Pembangunan nasional dari desa tercantum dalam Undang-Undang Nomor 6 Tahun 2014 tentang Desa yang bertujuan memperkuat kemandirian desa dalam mewujudkan keadilan yang merata. Lihat Sugiayanto, Urgensi dan Kemandirian Desa dalam Presfektif Undang-Undang No 6 Tahun 2014, Yogyakarta: Deepublish, 2017, hlm. 12.

${ }^{2}$ Ketentuan ini ditentukan dalam Pasal 87 UndangUndang Nomor 6 Tahun 2014

${ }^{3}$ Detik News, "Tingkatkan Perekonomian Desa, 74 Ribu Desa Bakal Terima Dana Rp 1,4 Miliar", www.news.detik.com diakses pada 6 Januari 2016

4 Harian Kompas, "Jumlah BUMDes Mencapai 18.446 Unit", www.ekonomi.kompas.com diakses pada 4 April 2017.
}

sebagai bagian dari proses pengelolaan keuangan desa agar lebih optimal dan memberikan pemasukan bagi desa. Dengan pembentukan BUMDes, Desa diharapkan ikut berperan dalam menghasilkan barang dan/atau jasa yang diperlukan dalam rangka mewujudkan sebesar-besarnya kemakmuran masyarakat desa, dan menjadi sumber PADes, sehingga APBDes tidak hanya bergantung pada Anggaran Dana Desa dan Bantuan Desa.

Permasalahan yang timbul dalam pembangunan desa melalui pendirian BUMDes muncul ketika pembentukan BUMDes hanya berorientasi pada segi kuantitas. Padahal dana yang dialokasikan untuk desa sekitar Rp. 20 Triliun yang dibagi pada 74 ribu desa, sehingga tiap desa akan menerima Rp 240 Juta, $^{3}$ belum termasuk Alokasi Dana Desa (ADD) dari Kabupaten, sementara jumlah BUMDes Tahun 2017 mencapai 18.446 unit. $^{4}$

Tidak hanya orientasi kuantitas yang menjadi persoalan, tolok ukur sumber daya baik manusia maupun jenis usaha juga menjadi permasalahan. Hal ini penting untuk diteliti, melihat kegagalan Koperasi Unit Desa pada masa sebelum BUMDes banyak dibentuk. ${ }^{5}$ Pembentukan BUMDes harus mempertimbangkan aspek pembangunan daerah yang terangkum

\footnotetext{
${ }^{5}$ Kegagalan Koperasi Unit Desa banyak disebabkan oleh lemahnya pengelolaan KUD tersebut. KUD dalam pembentukan awal digagas untuk membangkitkan atau menjadi penyokong usaha pertanian dan program-program pemerintah dalam rangka pemberdayaan desa, namun karena kesalahan dalam pembinaannya, akhirnya koperasi malah menjadi momok bagi masyarakat. Lihat Soedarsono Hadisapoetro, Badan Usaha Unit Desa dan Pembinaannya, dalam Pemikiran dan Permasalahan Ekonomi Indonesia Setengah Abad Terakhir: Buku 3 (1966-1982) Paruh Pertama Ekonomi Orde Baru, Yogyakarta: Kanisius, 2005, hlm. 95 .
} 
dalam RPJMD dan sinergitas tiap kecamatan, sehingga tiap kecamatan bisa saling mendukung. Pembangunan BUMDes yang tidak memperhatikan aspek kualitas, berpotensi menyebabkan kerugian dalam pengelolaan keuangan desa, dan tentu saja pendirian BUMDes tidak memiliki implikasi apapun dalam pembangunan Desa. Saat ini terdapat 4 Desa di kecamatan Babalan, desa-desa tersebut adalah Desa Pelawi Selatan, Desa Securai Selatan, Desa Securai Utara dan Desa Teluk Meku. ${ }^{6}$

\section{PEMBAHASAN}

\section{Definisi dan Perkembangan Desa}

H.W. Widjaja dalam bukunya yang berjudul "Otonomi Desa" menyatakan bahwa "Desa adalah sebagai kesatuan masyarakat hukum yang mempunyai susunan asli berdasarkasan hak asal-usul yang bersifat istimewa". Landasan pemikiran dalam mengenai Pemerintahan Desa adalah keanekaragaman, partisipasi, otonomi asli, demokratisasi dan pemberdayaan masyarakat. $^{7}$

Dalam Pasal 1 angka 1 UndangUndang Nomor 6 Tahun 2014, Desa didefinisikan sebagai “......kesatuan masyarakat hukum yang memiliki batas wilayah yang berwenang untuk mengatur danmengurus urusan pemerintahan, kepentingan masyarakat setempat berdasarkan prakarsa masyarakat, hak asal usul, dan/atau hak tradisional yang diakui dan dihormati dalam sistempemerintahan Negara Kesatuan Republik Indonesia".

Sebelum dibentuk Undang-Undang yang

${ }^{6}$ BPS Langkat, Kecamatan Babalan dalam Angka 2017, Stabat: BPS Langkat, 2017, hlm. 11.

7 H. AW Widjaja, Pemerintahan Desa dan Administrasi Desa Menurut Undang-Undang secara khusus mengatur tentang desa, pengaturan desa dimasukkan dalam rangkaian peraturan tentang pemerintahan daerah. beberapa undang-undang yang mengatur tentang desa sejak awal kemerdekaan hingga sebelum undangundang desa dibentuk antara lain: UndangUndang Nomor 22 Tahun 1948 tentang Pokok Pemerintahan Daerah, undangundang ini secara khusus menyatakan jika desa memiliki kewenangan otonom dalam mengatur daerahnya sendiri. Jika dilihat, kewenangan otonom desa yang diatur dalam undang-undang ini menunjukkan jika pada awal semangat pembentukan desa adalah dalam rangka memberikan jaminan hukum, bahwa desa dapat memberdayakan masyarakatnya secara penuh.

Kemudian, Undang-Undang Nomor 1 Tahun 1957 tentang Pokok pokok Pemerintahan Daerah, Undang-Undang Nomor 19 Tahun 1965 Tentang Desa Praja. Dalam Undang-Undang Nomor 19 Tahun 1965, desa ditempatkan sebagai Daerah Tingkat III dengan tata dan sebutan Desa Praja. Terdapat kesamaan antara pengaturan Inlandshe Gemeente Ordonantie dan Inlandshe Gemeente Ordonantie voor Buitengewesten dalam hal memandang desa sebagai sebuah kesatuan masyarakat hukum (volkgemeenschappen) yang memiliki hak adat istiadat dan asal usul. Dengan demikian berdasarkan peraturan perundang-undangan ini, nama, jenis, dan bentuk desa sifatnya tidak seragam.

Sejak peralihan kekuasaan, dari orde lama ke orde baru, pengaturan tentag desa kemudian dirubah melalui Undang-Undang

Nomor 5 Tahun 1979, Jakarta: Raja Grafindo Persada, 2002, hlm. 3. 
Nomor 5 Tahun 1979 tentang Pemerintahan Desa. Undang-Undang ini, mengatur ulang kewenangan desa dan menghilangkan keberagaman desa yang sebelumnya diatur dalam Undang-Undang Nomor 19 Tahun 1965. ${ }^{8}$

Desa dianggap sama tanpa memandang hak asal usulnya, bahkan kedudukan desa berada di bawah kecamatan. Baru di era reformasi, melalui Undang-Undang Nomor 22 Tahun 1999 tentang Pemerintahan Daerah, desa mendapatkan kembali haknya untuk mengatur berdasarkan hak asalusulnya. Selanjutnya dalam UndangUndang Nomor 32 Tahun 2004 Tentang Pemerintahan Daerah, desa diatur dalam 16 Pasal yaitu dari pasal 200-216, selanjtnya pengaturan tentang desa dalam UndangUndang Nomor 32 Tahun 2004 dijabarkan dalam Peraturan Pemerintah Nomor 72 Tahun 2005 tentang Desa. Dalam hal kewenangan secara prinsipil tidak ada perubahan yang mendasar dalam pengaturan mengenai kewenangan desa. Seperti halnya dengan Undang-Undang Nomor 22 Tahun 1999, desa memiliki kewenangan untuk mengatur dan mengurus kepentingan masyarakat setempat berdasarkan asal-usul dan adat-istiadat setempat yang diakui dalam sistem pemerintahan nasional dan berada di daerah kabupaten.

Dengan berlakunya Undang-Undang Nomor 6 tahun 2014 tentang Desa, maka

\footnotetext{
8 Penyeragaman dimulai dari Undang-Undang Nomor 5 tahun 1974 tentang Pokok-Pokok Pemerintahan Daerah, dalam Undang-Undang ini terjadi penyeragaman bentuk masyarakat adat di daerah maupun di desa. Oleh sebab itu konsep penyeragaman dalam Undang-Undang Nomor 5 Tahun 1974 juga diadopsi dalam Undang-Undang Nomor 5 tahun 1979. Lihat Ade Saptomo, Hukum dan Kearifan Lokal: RevitalisasiHukum Adat Nusantara, Jakarta: Grasindo, 2010, hlm. 14.
}

kedudukan desa baik secara asal-usul maupun kewenangan mengatur (otonomi) ruah tangganya mendapatkan kepastian. Kepastian pengelolaannya tidak hanya di bidang pemerintahan semata bahkan mencakup pengelolaan anggaran dan pembangunan desa berdasarkan prakarsa desa dan masyarakat desa, sehingga kebutuhan desa dapat dipenuhi oleh pemerintah desa.

Disahkannya Undang-Undang Nomor 6 Tahun 2014 tentang Desa bukan berarti tanpa masalah. Sebagaimana diketahui, sebelum Undang-Undang Desa dibentuk, seluruh pengaturan tentang desa menjadi bagian yang tidak terpisahkan dari pemerintah daerah yang menjadi kewenangan Kementerian Dalam Negeri melalui Direktorat Jendral Pemberdayaan Masyarakat Desa. Namun sejak Tahun 2014, lahir kementerian dengan nomenklatur baru yaitu Kementerian Desa, Pembangunan Daerah Tertinggal dan Transmigrasi. Namun akhirnya, pemerintah melalui Peraturan Presiden Nomor 11 Tahun 2015 dan Peraturan Presiden Nomor 12 Tahun $2015^{9}$ membagi peran terhadap desa pada dua kementerian. Urusan administrasi pemerintahan menjadi wewenang Kementrian Dalam Negeri sedangkan urusan pembangunan, pembinaan, dan pemberdayaan masyarakat Desa menjadi wewenang Kementrian Desa, Pembangunan Daerah Tertinggal dan

\footnotetext{
${ }^{9}$ Isi substantif Peraturan Presiden Nomor 12 Tahun 2015, memberikan Kementerian Desa kekuatan otoritatif untuk mengawal Pembangunan dan Pemberdayaan Masyarakat Desa dan Pembangunan Kawasan Perdesaan. Di lain pihak, konsekuensi dari peraturan presiden ini adalah menyisakan otoritas residu urusan administrasi pemerintahan umum yang menjadi tugas Kemendagri (Ditjen Bina Pemerintahan Desa).
} 
Transmigrasi. ${ }^{10}$

Berikut skema pembagian kewenangan antara Kementerian Dalam Negeri dan
Kementerian Desa dalam hal kewenangannya terkait Desa:

\begin{tabular}{|c|c|c|}
\hline $\begin{array}{l}\text { Urusan } \\
\text { Pemerintahan }\end{array}$ & $\begin{array}{lll}\text { Kemendesa, } & \text { PDT } & \text { dan } \\
\text { Transmigrasi } & & \\
\end{array}$ & Kementerian Dalam Negeri \\
\hline $\begin{array}{l}\text { Struktur } \\
\text { Organisasi }\end{array}$ & $\begin{array}{l}\text { Ditjen Pembangunan dan } \\
\text { Pemberdayaan Masyarakat } \\
\text { Desa }\end{array}$ & Ditjen Bina Pemerintahan Desa \\
\hline Tugas & $\begin{array}{l}\text { Pelayanan Sosial Dasar } \\
\text { Pengembangan Usaha Ekonomi } \\
\text { Desa } \\
\text { Pendayagunaan SDA dan TTG } \\
\text { Pembangunan Sarana dan } \\
\text { Prasarana Desa } \\
\text { Pemberdayaan Masyarakat Desa }\end{array}$ & $\begin{array}{l}\text { Penataan Desa } \\
\text { Administrasi Pemerintahan } \\
\text { Keuangan dan Aset Desa } \\
\text { Produk Hukum Desa } \\
\text { Pemilihan Kepala Desa } \\
\text { Perangkat Desa } \\
\text { Medebewind } \\
\text { Kelembagaan Desa } \\
\text { Kerjasama Pemerintahan } \\
\text { Evaluasi Perkembangan Desa }\end{array}$ \\
\hline & $\begin{array}{l}\text { Ditjen Pembangunan Kawasan } \\
\text { Pedesaan }\end{array}$ & \\
\hline Tugas & $\begin{array}{l}\text { Perencanaan Pembangunan } \\
\text { Kawasan Pedesaan } \\
\text { Pembangunan sarana dan } \\
\text { Prasarana Desa } \\
\text { Pembangunan Ekonomi Kawasan } \\
\text { Pedesaan }\end{array}$ & \\
\hline Kewenangan & Implementasi & Administrasi \\
\hline
\end{tabular}

Tabel 1. Skema Pembagian Kewenangan Kementerian Dalam Negeri dan Kementerian Desa terhadap Desa dalam Perpres Nomor 12 Tahun 2015 tentang Kementerian Desa, PDT dan Transmigrasi

Dalam tabel di atas, jelas dibedakan bentuk kewenangan antara Kementerian Desa, PDT dan Transmigrasi dan Kementerian Dalam Negeri, dimana
Kementerian Desa memiliki kewenangan implementatif sedangkan Kementerian Dalam Negeri memiliki kewenangan administratif.

10 Harian Republika, "Urusan Desa Tumpang Tindih Kewenangan", www.m.republika.co.id diakses 6 Januari 2016. 


\section{Pengaturan BUMDes}

Menurut Pasal 1 anga 2 Undang-Undang Nomor 25 Tahun 2004 tentang Sistem Perencanaan Pembangunan Nasional mendefinisikan Pembangunan Nasional sebagai upaya yang dilaksanakan oleh semua komponen bangsa dalam rangka mencapai tujuan bernegara. Dalam hal ini pembangunan nasional bertujuan untuk mewujudkan masyarakat adil dan makmur yang merata material dan spiritual berdasarkan Pancasila dan UndangUndang Dasar 1945 dalam wadah Negara Kesatuan Republik Indonesia yang merdeka, berdaulat, bersatu, dan berkedaulatan rakyat dalam suasana perikehidupan bangsa yang aman, tenteram, tertib, dan dinamis dalam lingkungan pergaulan dunia yang merdeka, bersahabat, tertib, dan damai. Pembangunan nasional sebagai pengamalan Pancasila yang mencakup seluruh aspek kehidupan bangsa diselenggarakan bersama oleh masyarakat dan Pemerintah.

Dalam rangka mewujudkan pembangunan nasional, maka perlu penguatan dasar-dasar pembangunan tersebut, dalam hal ini pembangunan desa sebagai salah satu dasar pembangunan nasional dari bawah (bottom-up). Pembangunan desa tidak dapat dipisahkan dari persoalan hukum sebagai landasan yuridis, ekonomi sebagai dasar pertumbuhan dan kemajuan dan budaya sebagai cerminan kearifan lokal suatu desa. ${ }^{11}$

Landasan yuridis memuat kerangka hukum pengaturan desa, baik mengenai
Anggaran Pendapatan Belanja Desa, Rencana Pembangunan Jangka menengah Desa dan kebijakan-kebijakan kepala desa dalam rangka membangunan desa. Kemudian ekonomi, sebagai dasar kemendirian desa yang dapat mendukung pemberdayaan masyarakat, dan berimplikasi pada salah satu sektor pendapatan asli desa. Sedangkan budaya menjadi nilai dasar dari perilaku dan bentuk pembangunan kawasan pedesaan berbasis kearifan lokal yang turun-temurun berkembang dan hidup dalam suatu masyarakat desa di Indonesia yang sangat heterogen.

Untuk menuju pemberdayaan dan kemandirian desa sebagai bagian dari pembangunan nasional, maka dibutuhkan kondisi keuangan desa yang sehat pula. Menurut Pasal 71 ayat 1 Undang-Undang Nomor 6 Tahun 2014 mendefinisikan keuangan desa sebagai semua hak dan kewajiban desa yang dapat dinilai dengan uang serta segala sesuatu berupa uang dan barang yang berhubungan dengan pelaksanaan hak dan kewajiban desa. Kemudian berdasarkan Pasal 72 ayat 1 Undang-Undang Nomor 6 tahun 2014 menyatakan keuangan desa terdiri dari: (1) Pendapatan Asli Desa (PADes) yang berasal dari hasil usaha (BUMDes), hasil aset, swadaya dan partisipasi, gotongroyong, dan lain-lain pendapatan asli Desa; (2) Alokasi Anggaran Pendapatan dan Belanja Negara (Dana Desa); (3) Bagian dari hasil pajak daerah dan retribusi daerah; (4) Alokasi Dana Desa yang merupakan bagian dari dana perimbangan yang diterima Kabupaten/Kota; (5) Bantuan

${ }^{11}$ Daldjoeni, A. Suyitno, Pedesaan, Lingkungan dan Pembangunan, Bandung: Alumni, 2004, hlm. 12. 
keuangan dari APBD Provinsi dan APBD Kabupaten / Kota; (6) Hibah dan sumbangan yang tidak mengikat dari pihak ketiga dan lain-lain pendapatan Desa yang sah.

Dari beberapa sumber keuangan desa, salah satu sektor yang paling dapat dihasilkan dan besar implikasinya terhadap pembangunan desa dan pemberdayaan ekonomi desa adalah hasil usaha desa yang dapat diperoleh dari pengelolaan BUMDes. Menurut Maryunani BUMDes didefinisikan sebagai lembaga usaha desa yang dikelolaoleh masyarakat dan pemerintahandesa dalam upaya memperkuat perekonomian desa dan membangun kerekatan sosial masyarakat yang dibentuk berdasarkan kebutuhan dan potensi desa. ${ }^{12}$ Pada Pasal 1 angka 6 Peraturan Menteri dalam Negeri Nomor 39 Tahun 2010, BUMDes didefinisikan sebagai usaha desa yang dibentuk/didirikan oleh pemerintah desa yang kepemilikan modal dan pengelolaannya dilakukan oleh pemerintah desa dan masyarakat. Sedangkan pada Pasal 1 anga 2 Peraturan Menteri Desa, PDT dan Trnasmigrasi Nomor 4 Tahun 2015 mendefinisikan BUMDes sebagai badan usaha yang seluruh atau sebagian besar modalnya dimiliki oleh Desamelalui penyertaan secara langsung yang berasal dari kekayaan
Desa yangdipisahkan guna mengelola aset, jasa pelayanan, dan usaha lainnya untuk sebesar-besarnya kesejahteraan masyarakat Desa.

Keberadaan BUMDes sebelum diatur dalam Undang-Undang Nomor 6 Tahun 2014 tentang desa dan segala aturan pelaksananya, terlebih dahulu diatur dalam Pasal 213 ayat 1 Undang-Undang Nomor 32 Tahun 2004 tentang Pemerintah Daerah yang saat ini telah diubah dengan UndangUndang Nomor 23 Tahun 2014. Rumusan Pasal 213 (1) Undang-Undang Nomor 32 Tahun 2004 tersebut adalah "Desa dapat mendirikan badan usaha milik desa sesuai dengan kebutuhan dan potensi desa". Rumusan yang sama diatur dalam Peraturan Pemerintah Nomor 72 Tahun 2005 tentang Desa. Peraturan Pelaksana yang lebih jelas diatur dalam Peraturan Menteri Dalam Negeri Nomor 39 Tahun 2010 tentang Badan Usaha Milik Desa. Sebelum akhirnya diatur dalam Peraturan Menteri Desa, PDT dan Transmigrasi Nomor 4 Tahun 2015.

Terdapat beberapa perbandingan ketentuan Badan Usaha Milik Desa yang diatur dalam Permendagri Nomor 39 tahun 2010 dan Permendesa Nomor 4 Tahun 2015, sebagaimana digambarkan dalam tabel berikut:

12 Maryunani, Pembangunan Bumdes dan Pemerdayaan Pemerintah Desa, Bandung: CV Pustaka Setia, 2008, hlm. 35. 


\begin{tabular}{|c|c|c|}
\hline Unsur & $\begin{array}{l}\text { Permendagri Nomor } 39 \text { Tahun } \\
2010\end{array}$ & Permendesa Nomor 4 Tahun 2015 \\
\hline $\begin{array}{l}\text { Pembentukan } \\
\text { BUMDes }\end{array}$ & $\begin{array}{l}\text { Tata cara pembentukan ditetapkan } \\
\text { dalam Peraturan Daerah }\end{array}$ & Tata cara merujuk pada Permendesa \\
\hline Sifat usaha & Usaha Desa & Badan Usaha \\
\hline $\begin{array}{l}\text { Dasar Hukum } \\
\text { Pembentukan }\end{array}$ & Peraturan Desa & Peraturan Desa \\
\hline $\begin{array}{l}\text { Mekanisme } \\
\text { Pembentukan }\end{array}$ & Musyawarah Desa & Musyawarah Desa \\
\hline $\begin{array}{l}\text { Bentuk } \\
\text { BUMDes }\end{array}$ & Tidak ada & $\begin{array}{l}\text { Perseroan Terbatas } \\
\text { Lembaga Keuangan Mikro }\end{array}$ \\
\hline $\begin{array}{l}\text { Organisasi } \\
\text { Pengelola }\end{array}$ & $\begin{array}{l}\text { Penasehat (Komisaris) } \\
\text { Pelaksana Operasional (Direksi) }\end{array}$ & $\begin{array}{l}\text { Penasehat } \\
\text { Pelaksana Operasional } \\
\text { Pengawas }\end{array}$ \\
\hline $\begin{array}{l}\text { Modal } \\
\text { BUMDes }\end{array}$ & $\begin{array}{l}\text { a. pemerintah desa; } \\
\text { b. tabungan masyarakat; } \\
\text { c. bantuan pemerintah, } \\
\text { pemerintah provinsi, dan } \\
\text { pemerintah kabupaten/kota; } \\
\text { d. pinjaman; dan/atau } \\
\text { e. kerja sama usaha dengan } \\
\text { pihak lain. }\end{array}$ & $\begin{array}{l}\text { a. hibah dari pihak swasta } \\
\text { b. bantuan Pemerintah, } \\
\text { Pemerintah Daerah Provinsi, } \\
\text { dan Pemerintah Daerah } \\
\text { Kabupaten } \\
\text { c. kerjasama usaha dari pihak } \\
\text { swasta, } \\
\text { d. aset Desa }\end{array}$ \\
\hline $\begin{array}{l}\text { Mekanisme } \\
\text { Penyertaan }\end{array}$ & Tidak dimasukan dalam APBDes & $\begin{array}{l}\text { Telebih dahulu dimasukan dalam } \\
\text { APBDes }\end{array}$ \\
\hline $\begin{array}{l}\text { Jenis } \\
\text { Penyertaan }\end{array}$ & Kekayaan Desa yang dipisahkan & Tidak diatur \\
\hline Jenis Usaha & $\begin{array}{l}\text { a. jasa; } \\
\text { b. penyaluran sembilan bahan } \\
\text { pokok; } \\
\text { c. perdagangan hasil pertanian; } \\
\text { dan/atau } \\
\text { d. industri kecil dan rumah } \\
\text { tangga. }\end{array}$ & $\begin{array}{ll}\text { a. } & \text { Serving } \\
\text { b. } & \text { Renting } \\
\text { c. } & \text { Brokering } \\
\text { d. } & \text { Trading } \\
\text { e. } & \text { Financial Bussiness }\end{array}$ \\
\hline Pembinaan & $\begin{array}{l}\text { Menteri, Gubernur, Bupati dan } \\
\text { Walikota }\end{array}$ & $\begin{array}{l}\text { Menteri, Gubernur, Bupati dan } \\
\text { Walikota }\end{array}$ \\
\hline Pengawasan & $\begin{array}{l}\text { BPD dan Pengawas Internal } \\
\text { Inspektorat Kabupaten }\end{array}$ & Pengawas (organisasi pengelola) \\
\hline
\end{tabular}

\section{Tabel 2. Matriks Pengaturan BUMDes}

Dari matriks diatas dapat dilihat ini dikarenakan Desa lebih otonom dalam perbedaan pengaturan terkait BUMDes. Kelemahan dari Permendes saat ini adalah peran dari pemerintah daerah untuk terlibat lebih jauh dalam upaya mengontrol kinerja BUMDes yang dilaksanakan oleh desa. Hal upaya mengelola keuangan desa dan bentuk penyertaan modal pada BUMDes yang belum dapat dikontrol dengan baik oleh daerah. Peran daerah hanya terbatas pada pembinaan saja. Berbeda dengan 
Permendagri yang lebih memberikan porsi pada pemerintah daerah dalam upaya melakukan pembinaan dan pengawasan dalam pelaksanaan BUMDes oleh desa.

\section{Praktik Penyelenggaraan BUMDes di Kecamatan Babalan}

Sebelum dianalisis pembentukan Badan Usaha Mili Desa di Desa dalam Lingkup Kecamatan Babalan, maka terlebih dahulu diuraikan kondisi Anggaran Pendapatan dan Belanja Desa (APBDes) di empat desa dalam Tahun Anggaran 2017.

\section{a. Desa Pelawi Selatan}

Berdasarkan Peraturan Desa Nomor 1 Tahun 2017 tentang Anggaran Pendapatan dan Belanja Desa diuraikan jumlah pendapatan dan belanja desa. Berikut uraian APBDes sebagaimana dalam tabel:

\begin{tabular}{|c|c|}
\hline $\begin{array}{c}\text { Pendapatan Asli Desa } \\
\text { - } \quad \text { Swadaya } \\
\text { Masyarakat }\end{array}$ & 2.000 .000 \\
\hline \begin{tabular}{rll}
\multicolumn{3}{l}{ Pendapatan Transfer } \\
- & Dana Desa \\
- & Bagi Hasil \\
& Pajak & \\
- & Alokasi & Dana \\
& Desa &
\end{tabular} & $\begin{array}{l}868.797 .000 \\
14.124 .000 \\
661.770 .000\end{array}$ \\
\hline Total & 1.546 .691 .000 \\
\hline Penyertaan Modal & 100.000 .000 \\
\hline
\end{tabular}

Tabel 3. Anggaran Pendapatan dan Belanja Desa Pelawi Selatan Tahun 2017

Desa pelawi selatan memiliki satu BUMDes yang bernama "Pelawi Selatan Permai". BUMDes tersebut bergerak di bidang Bisnis Keuangan. Bisnis Keuangan yang dimaksud dalam hal ini adalah usaha simpan pinjam. Usaha ini dijalankan oleh pengurus BUMDes dengan mengandalkan dana keseluruhan berasal dari penyertaan modal pemerintah desa. Pada Tahun 2016 Pemerintah Desa Pelawi Selatan menyertakan modal sebanyak Rp.20.000.000 yang keseluruhan dana penyertaan tersebut digunakan untuk usaha simpan pinjam dengan model pinjaman paling besar adalah 1 Juta per orang dengan bunga sekitar $12 \%$ pertahun. Pinjaman ini dibayarkan oleh kreditur setelah satu tahun masa pinjaman. Pembayaran dilakukan menyeluruh baik modal maupun bunga pinjamannya.

Pada tahun 2017, pemerintah desa kembali menyertaakan modal sebesar Rp.100.000.000, yang akan digunakan untuk jenis usaha yang sama yaitu simpan pinjam. Namun sampai pengumpulan data terakhir yang dilakukan peneliti, penyertaan Tahun 2017 belum juga kunjung dilakukan. Alasan hal tersebut adalah APBDes belum mengalokasikan anggaran di semester pertama. Lazimnya anggaran penyertaan modal tersebut diambil dari dana desa tahap kedua. Namun belajar dari penyertaan modal tahun sebelumnya. Penyertaan modal dilakukan pada akhir tahun anggaran di bulan Desember.

\section{b. Desa Securai Selatan}

Berdasarkan Peraturan Desa Nomor 1 Tahun 2017 tentang Anggaran Pendapatan dan Belanja Desa diuraikan jumlah pendapatan dan belanja desa. Berikut uraian APBDes sebagaimana dalam tabel: 


\begin{tabular}{|c|c|}
\hline \begin{tabular}{ll} 
Pendapatan Asli \\
Desa \\
- Hasil Usaha \\
\multicolumn{2}{c}{ Desa }
\end{tabular} & 5.000 .000 \\
\hline $\begin{array}{l}\text { Pendapatan } \\
\text { Transfer } \\
\text { - Dana Desa } \\
\text { - } \quad \text { Bagi Hasil } \\
\\
\text { Pajak } \\
\text { - Alokasi } \\
\quad \text { Dana Desa }\end{array}$ & $\begin{array}{l}944.524 .000 \\
18.750 .000 \\
820.341 .000\end{array}$ \\
\hline Total & 1.788 .615 .000 \\
\hline Penyertaan Modal & 50.000 .000 \\
\hline
\end{tabular}

Tabel 4. Anggaran Pendapatan dan Belanja Desa Securai Selatan Tahun 2017

Desa Securai Selatan memiliki BUMDes dengan bentuk perseroan terbatas yang diberi nama "PT Sutan Karya Utama. Perseroan terbatas ini dibentuk pada tahun 2014 dengan status perseroan bukan milik desa karena desa Securai Selatan belum menyertakan modal pada saat pendiriannya. Setelah diundangkannya Peraturan Menteri Desa, PDT dan Transmigrasi Nomor 4 Tahun 2015, maka PT Sutan Karya Utama dijadikan BUMDes dengan mekanisme merger yang tidak jelas. Hal ini dapat dilihat dari cara PT Sutan Karya Utama yang tiba-tiba dijadikan BUMDes. Pada Tahun 2016, pemerintah desa menyertakan modal sebesar Rp.25.000.000, dan berdasarkan keterangan direktur BUMDes, sebanyak Rp.7000.000 anggaran sebanyak Rp. 25.000.000 tersebut dianggap sebagai biaya merger PT Sutan Karya Utama oleh pemerintah desa, sehingga sisanya sebanyak Rp.18.000.000 dijadikan modal untuk kegiatan BUMDes yang bergerak di bidang simpan pinjam, dan pembelian tenda ukuran 5X4 Meter sebanyak 2 Unit dan Mesin Pengaduk Beton yang dijadikan sebagai alat yang dapat disewa oleh penduduk desa, sisanya menjadi modal untuk simpan pinjam.

Pada Tahun 2017, pemerintah desa kembali menganggarkan Rp. 50.000.000 sebagai penyertaan modal kembali pada PT Sutan Karya Utama yang menurut proposal pengajuan akan digunakan untuk usaha simpan pinjam. Penyertaan modal Tahun 2017 sebanyak Rp. 50.000 .000 belum juga diterima oleh pengurus BUMDes hingga observasi dilakukan oleh peneliti.

\section{c. Desa Securai Utara}

Berdasarkan Peraturan Desa Nomor 1 Tahun 2017 tentang Anggaran Pendapatan dan Belanja Desa diuraikan jumlah pendapatan dan belanja desa. Berikut uraian APBDes sebagaimana dalam tabel:

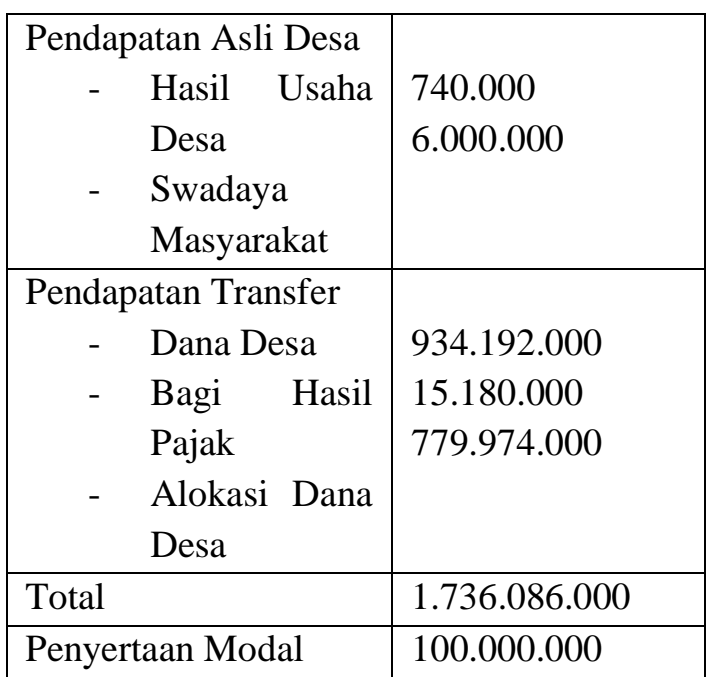

Tabel 5. Anggaran Pendapatan dan Belanja Desa Securai Utara Tahun 2017

Desa Securai Utara memiliki BUMDes dengan nama "Makmur" yang bergerak di bidang usaha simpan-pinjam, dan perdagangan Gas LPG Subsidi Ukuran 3 
Kg. Pada Tahun 2016 pemerintah desa menyertakan modal sebesar Rp.20.000.000 sebagai modal awal BUMDes Makmur. Usaha sebelumnya adalah usaha Pengepulan Sawit, namun dirasa tidak menguntungkan oleh pengurus, kemudian dialihkan ke usaha perdagangan Gas LPG. Pada tahun anggaran 2017, pemerintah desa melakukan penyertaan modal kembali sebesar Rp. 100.000.000 yang akan digunakan untuk jenis usaha simpanpinjam, perdagangan, dan penjualan pupuk dan alat pertanian. Namun anggaran tersebut belum diterima oleh BUMDes sampai saat ini karena beberapa laporan belum diselesaikan oleh pengurus.

\section{d. Desa Teluk Meku}

Berdasarkan Peraturan Desa Nomor 1 Tahun 2017 tentang Anggaran Pendapatan dan Belanja Desa diuraikan jumlah pendapatan dan belanja desa. Berikut uraian APBDes sebagaimana dalam tabel:

\begin{tabular}{|c|c|}
\hline $\begin{array}{l}\text { Pendapatan Asli } \\
\text { Desa } \\
\\
\\
\text { Lain-Lain } \\
\\
\text { Pendapatan } \\
\text { yang sah } \\
\end{array}$ & 6.880 .305 \\
\hline $\begin{aligned} & \text { Pendapatan Transfer } \\
& \text { - } \text { Dana Desa } \\
& \text { - } \text { Bagi Hasil } \\
& \text { Pajak } \\
& \text { - } \text { Alokasi } \\
& \text { Dana Desa }\end{aligned}$ & $\begin{array}{l}933.607 .000 \\
26.215 .000 \\
817.962 . .000\end{array}$ \\
\hline Total & 1.784 .487 .000 \\
\hline Penyertaan Modal & 50.000 .000 \\
\hline
\end{tabular}

Tabel 6. Anggaran Pendapatan dan Belanja Desa Teluk Meku Tahun 2017

\footnotetext{
13 Arif Rahman, Untung Besar dari Reksadana, Yogyakarta: MED Press, 2010, hlm. 3.
}

Desa Teluk Meku memiliki BUMDes yang diberinama "Teluk Jaya". Bumdes ini bergerak di bidang usaha simpan pinjam. Pada tahun 2016 modal pertama yang disertakan pemerintah desa sebesar Rp.20.000.000 yang keseluruhannya dijadikan modal usaha simpan-pinjam. Pada Tahun 2017 pemerintah desa kembali menganggarkan Rp.50.000.000 untuk disertakan pada BUMDes guna usaha "Warung Internet". Namun anggaran tahun 2017 belum juga diterima BUMDes karena anggaran pemerintah desa yang berasal dari Dana Desa tahap dua belum diterima pemerintah desa.

\section{Analisis Hukum Pembentukan Badan Usaha Milik Desa di Kecamatan Babalan}

\section{a. Investasi Tidak Produktif}

Penyertaan Modal dapat diartikan sebagai investasi pemerintah desa kepada suatu BUMDes yang diharapkan mampu menjadi perangsang tumbuhnya kondisi perekonomian penduduk desa. Menurut Kamus Umum Besar Bahasa Indonesia, investasi diartikan sebagai penanaman uang atau di suatu perusahaan atau proyek untuk tujuan memperoleh keuntungan. Pada dasarnya investasi adalah membeli suatu aset yang diharapkan di masa datang dapat dijual kembali dengan nilai yang lebih tinggi. ${ }^{13}$

Menurut Tandelilin pada umumnya investor digolongkan menjadi dua, yaitu investor individual yang terdiri dari individu-individu yang melakukan aktivitas investasi dan investor institusional yang biasanya terdiri dari perusahaan perusahaan asuransi, lembaga 
penyimpanan dana (bank dan lembaga simpan-pinjam), lembaga dana pensiun, maupun perusahaan investasi. ${ }^{14}$

Sebagaimana diuraikan di atas, terdapat 4 jenis usaha yang dapat dijadikan sasaran BUMDes yaitu Serving, Renting, Brokering, Trading dan Financial Bussines. Namun sasaran BUMDes tersebut juga harus memperhatikan jenis usaha yang sudah menjadi penghasilan sebagaian besar penduduk desa. Tujuan pendirian BUMDes sebagaimana diatur dalam Pasal 3 Permendesa Nomor 4 tahun 2015 antara lain adalah

1. Meningkatkan perekonomian Desa;

2. Mengoptimalkan aset Desa agar bermanfaat untuk kesejahteraan Desa;

3. Meningkatkan usaha masyarakat dalam pengelolaan potensi ekonomi Desa;

4. Mengembangkan rencana kerja sama usaha antar desa dan/atau dengan pihak ketiga;

5. Menciptakan peluang dan jaringan pasar yang mendukung kebutuhan layanan umum warga;

6. Membuka lapangan kerja;

7. Meningkatkan kesejahteraan masyarakat melalui perbaikan pelayanan umum, pertumbuhan dan pemerataan ekonomi Desa; dan

8. Meningkatkan pendapatan masyarakat Desa dan Pendapatan Asli Desa

Berdasarkan penelusuran yang dilakukan di desa-desa tersebut, BUMDes rata-rata bergerak di sektor Financial Bussiness, atau simpan-pinjam. Namun

14 Eduardus Tandelin, Analisis Investasi dan Manajemen Portfolio, Edisi Pertama, Yogyakarta: BPFE-Yogyakarta, 2001, hlm. 4. sampai saat ini, hanya peminjaman saja yang dilakukan oleh BUMDes tanpa ada upaya untuk mengarah pada bentuk simpanan dari nasabah, sehingga dapat disimpulkan jika usaha simpan-pinjam yang dilakukan tidak produktif terbelih lagi skema pengembalian dilakukan menjelang akhir tahun. Terlebih lagi ketidakjelasan bentuk hukum BUMDes. Sebagaimana diketahui bentuk-bentuk badan usaha ada yang berbada hukum dan tidak berbadan hukum. Terlebih lagi penunjukkan sumber daya manusia BUMDes harus memiliki kapabilitas dalam pengelolaan anggaran.

Lazimnya suatu investasi yang dilakukan pemerintah desa melihat potensi keuntungan yang akan diperoleh BUMDes berdasarkan usulan proposal yang diajukan BUMDes. Mengutip pendapat Tendelin yang menyatakan alasan utama seseorang berinvestasi adalah untuk memperoleh keuntungan dan dalam konteks manajemen investasi tingkat keuntungan investasi disebut return. ${ }^{15}$

Dalam praktiknya, BUMDes justru terlebih dahulu dijanjikan mendapatkan anggaran penyertaan dari pemerintah desa, baru kemudian BUMDes membentuk proposal pengajuan penyertaan modal. Hal ini menjadikan BUMDes sebagai badan usaha yang dipaksakan demi tercapainya program pendirian BUMDes, sehingga BUMDes dapat menerima modal segar dari pemerintah desa tanpa perlu menunjukkan program usaha, dan resiko bisnis yang akan dihadapi di kemudian hari. Sehingga apa yang dikhawatirkan oleh peneliti yaitu BUMDes menjadi bentuk pengulangan kebijakan Koperasi Unit Desa di sera orde

\footnotetext{
${ }^{15}$ Eduardus Tendelin, Op., cit, hlm. 5.
} 
baru.

Di sisi lain, bentuk pengawasan oleh pemerintah daerah sangat kecil, melihat kedudukan pemerintah daerah hanya terbatas dalam hal membina dan mengevaluasi, sedangkan unsur pengawas dilakukan oleh organ BUMDes sendiri sebagaimana diatur dalam Pasal 19 ayat 1 Permendesa Nomor 4 tahun 2015 yang menyatakan bahwa organisasi pengurus BUMDes terdiri dari Penasehat, Pelaksana Operasional dan Pengawas.

\section{b. Masalah Bentuk Badan Usaha}

Sebagai badan usaha yang memiliki modal besar, terutama modal dari pemerintah desa, lazimnya BUMDes harus memiliki bentuk badan usaha guna memberikan landasan yuridis pengelolaan badan usaha dan pengembangannya, baik berbentuk badan hukum atau tidak. Pemilihan bentuk badan usaha disesuaikan dengan modal yang dimiliki. Adapun bentuk badan usaha antara lain adalah:

1. Perusahaan Perseorangan Perusahaan Perseorangan merupakan perusahaan yang dimiliki dan diawasi oleh satu orang saja, lazimnya perusahaan ini dimiliki oleh orang pribadi dan menjalankan usaha di sektor kecil dan menengah. Perusahaan perseorangan memiliki kelebihan dalam pembentukannya, namun untuk memperoleh modal tambahan sulit dilakukan, terlebih jumlahnya besar. Modal perusahaan dan kekayaan pribadi sulit dibedakan dalam jenis badan usaha perseorangan, sehingga jika terjadi kerugian otomatis

16 M Fuad, et al, Pengantar Bisnis, Jakarta: Gramedia Pustaka Utama, 2006, hlm. 64. berimplikasi pada harta pribadi. ${ }^{16}$

\section{Firma}

Firma merupakan bentuk badan usaha yang sama dengan perusahaan perseorangan, namun Firma didirikan oleh beberapa orang dalam suatu usaha bersama. Firma dikelola secara bersama-sama dan kerugian juga ditanggung bersama-sama. Utang perusahaan juga harus ditanggung bersama bahkan kekayaan pribadi juga tidak terpisah dari kekayaan perusahaan. ${ }^{17}$

\section{Perseroan Commanditer}

Perseoran commanditer merupakan bentuk perluasan dari perusahaan Firma. Dalam perseroan komanditer, para pihak terbagi dalam dua jenis sekutu; pertama, sekutu kompelemeter yang bersedia ditunjuk untuk menjalankan usaha dan memimpin perusahaan dengan bertanggungjawab penuh dengan kekayaan pribadinya; kedua, sekutu komanditer adalahs ekutu yang mempercayakan kekayaannya dan bertanggungjawab hanya terbatas pada modal yang disertakan. ${ }^{18}$

\section{Perseroan Terbatas}

Perusahaan ini berbeda dari yang diuraikan di atas. Perbedaannya terletak pada status perseroan terbatas sebagai badan hukum dan tunduk pada teori badan hukum dimana suatu perseroan terbatas memiliki kekayaan sendiri yang terpisah dari kekayaan pemilik

17 Elsi Kartika Sari, Advendi Simangunsong, Hukum Dalam Ekonomi, Jakarta: Grasindo, 2008, hlm. 53.

${ }^{18}$ M Fuad, Op., Cit, hlm 66. 
modal. Sebagai badan hukum (rechtpersoon), perseroan terbatas memiliki hak dan kewajiban layaknya manusia (natuurlijkpersoon). ${ }^{19}$

Berdasarkan Pasal 7 Permendesa Nomor 4 Tahun 2015, (1) BUMDesa dapat terdiri dari unit-unit usaha yang berbadan hukum; (2) Unit usaha yang berbadan hukum sebagaimana dimaksud pada ayat (1) dapat berupa lembaga bisnis yang kepemilikan sahamnya berasal dari BUM Desa dan masyarakat; (3) Dalam hal BUM Desa tidak mempunyai unit-unit usaha yang berbadan hukum, bentuk organisasi BUM Desa didasarkan pada Peraturan Desa tentang Pendirian BUM Desa.

Sedangkan dalam Pasal 8 Permendesa Nomor 4 Tahun 2015, BUMDesa dapat membentuk unit usaha meliputi: a. Perseroan Terbatas sebagai persekutuan modal, dibentuk berdasarkan perjanjian, dan melakukan kegiatan usaha dengan modal yang sebagian besar dimiliki oleh BUM Desa, sesuai dengan peraturan perundang-undangan tentang Perseroan Terbatas; dan b. Lembaga Keuangan Mikro dengan andil BUMDesa sebesar 60 (enam puluh) persen, sesuai dengan peraturan perundang-undangan tentang lembaga keuangan mikro.

Jika dilihat perintah Permendesa, mengarahkan pendirian BUMDes dan unit usahanya ke arah Badan Hukum, hal ini dapat dipahami, dengan unit usaha yang berbadan hukum, maka akses modal, dan jaminan hukum terhadap operasional BUMDes dijamin dalam hukum. Praktiknya berbeda dengan yang ada di desa sampel. Desa Securai Utara, Desa

${ }^{19}$ R. Ali Rido, Badan Hukum dan kedudukan Badan Hukum Perseroan, Perkumpulan, Koperasi,
Pelawi Utara dan Desa Teluk Meku tunduk pada bentuk badan usaha yang disepakati dalam Peraturan Desa masing-masing tentang BUMDes yang membentuk BUMDes sama seperti membentuk perusahaan perseorangan, dimana pemerintah desa menjadi satu-satunya penyerta modal tanpa ada pihak lain. Sementara Desa Securai Selatan membentuk BUMDes dengan bentuk perseroan terbatas, namun bagaimana operasional PT yang didirikan tahun 2014 dapat tiba-tiba menjadi BUMDes. Jika dianalisis secara hukum, maka penyertaan modal pemerintah desa Securai Selatan selama Tahun 2016 sebesar R. 25.000.000 tidak serta merta menjadikan PT Sutan Karya Utama sebagai BUMDes.

Berdasarkan Pasal 5 Permendesa Nomor 4 Tahun 2015, dinyatakan jika "Pendirian BUMDes disepakati memalui musyawarah desa. Sedangkan pendirian PT Sutan Karya Utama dilakukan pada Tahun 2014 dengan struktur pengurus yang sudah dibentuk dari awal. Kemudian hal ini berimplikasi pada unsur pengawas BUMDes yang merupakan bagian terpisah dari PT Sutan Karya Utama, sedangkan Pengawas BUMDes ditunjuk dapat melakukan Rapat Umum Pemegang Saham dan berhak mengsulkan direksi sebagaimana diatur dalam Pasal 15 auat 3 dan 4 Permendesa Nomor 4 Tahun 2015.

\section{c. Implikasi terhadap Pendapatan Asli Desa}

Sebagaimana diatur dalam Pasal 3 Permendesa Nomor 4 tahun 2015 yang menjadikan tujuan pendirian BUMDes dapat Meningkatkan pendapatan

Yayasan dan Wakaf, Bandung: Alumni, 2004, hlm. 53. 
masyarakat Desa dan Pendapatan Asli Desa. Maka harus dilihat bagaimana pengelolaan deviden BUMDes dalam hal memenuhi salah satu tujuan pendiriannya dalam meningkatkan Pendapatan Asli Desa (PADes). Berdasarkan Pasal 26 ayat 2 Permendesa Nomor 4 tahun 2015 dinyatakan "Pembagian hasil usaha BUMDesa ditetapkan berdasarkan ketentuan yang diatur dalam Anggaran Dasar/Anggaran Rumah Tangga BUM Desa. Dalam hal ini jika BUMDes tidak berbentuk badan hukum, maka pembagian hasil usaha (deviden) harus merujuk pada AD/ART BUMDes yang berdasarkan hasil penelusuran peneliti mengalokasikan sekitar $10 \%$ hasil usaha setelah dikurangi beban operasional dan penyusutan. Namun berbeda implikasinya jika BUMDes berbentuk badan hukum perseroan terbatas yang juga tunduk pada Undang-Undang Nomor 40 tahun 2007 tentang Persoran Terbatas yang mengatur jumlah deviden harus sesuai dengan jumlah persentase modal yang diserahkan.

Sampai saat ini, belum ada dampak serius pendirian BUMDes terhadap meningkatnya PADes. Berdasarkan hasil penelusuran peneliti terhadap BUMDes di desa dalam lingkup Kecamatan Babalan menunjukkan persentase yang sangat kecil dari deviden yang diberikan BUMDes kepada pemerintah desa. Hal ini dapat dilihat dari salah satu sumber PADes sebagaimana diuraikan dalam Tabel 3, 4, 5 dan 6.

\section{PENUTUP}

Berdasarkan hasil penelitian yang belum terlaksana sepenuhnya, maka hasil dan saran dari penelitian ini masih bersifat pendapat sementara dan akan diuji kembali melalui analisis komprehensif terhdapa bahan-bahan yang sudah didapatkan dari hasil kunjungan ke daerah sampel. Adapun pendapat sementara dalam penelitian ini sebagaimana diuraikan berikut:

1. Proses pembentukan BUMDes di Desa dalam kecamatan Babalan belum sepenuhnya berjalan dengan baik. Pembentukan dilakukan secara tergesa-gesa dikarenakan "paksaan" dalam peraturan perundang-undangan tentang BUMDes. Pembentukan BUMDes terlihat lebih disebabkan adanya anggaran desa yang harus disertakan dalam BUMDes, sehingga bentuk BUMDes seakan dipaksakan tanpa ada musyawarah dari seluruh elemen masyarakat desa.

2. Mekanisme penyertaan modal ke BUMDes masih belum sesuai peraturan. Lazimnya BUMDes terlebih dahulu mempresentasekan proposal dan mengusulkan jumlah yang dibutuhkan, namun praktiknya, besaran anggaran terlebih dahulu dijanjikan oleh kepala desa bahkan sebelum proposal diajukan oleh BUMDes kepada kepala desa. Akhirnya, Proposal BUMDes menyesuaikan anggaran proposal dengan jumlah yang dijanjikan oleh Kepala Desa.

3. BUMDes belum berperan signifikan dalam upaya meningkatkan pendapatan asli desa, hal ini dapat dilihat dari APBDes Tahun 2016 dimana BUMDes belum menyetorkan deviden untuk dijadikan salah satu unsur pendapatan asli desa. 


\section{DAFTAR PUSTAKA}

\section{Buku}

Ade Saptomo, Hukum dan Kearifan Lokal: RevitalisasiHukum Adat Nusantara, Jakarta: Grasindo, 2010

Arif Rahman, Untung Besar dari Reksadana, Yogyakarta: MED Press, 2010

BPS Langkat, Kecamatan Babalan dalam Angka 2017, Stabat: BPS Langkat, 2017

Daldjoeni, A. Suyitno, Pedesaan, Lingkungan dan Pembangunan, Bandung, PT. Alumni, 2004

Eduardus Tandelin, Analisis Investasi dan Manajemen Portfolio, Edisi Pertama. Yogyakarta, BPFE-Yogyakarta, 2001

Elsi Kartika Sari, Advendi Simangunsong, Hukum Dalam Ekonomi, Jakarta, Grasindo, 2008

M Fuad, et. al, Pengantar Bisnis, Jakarta: Gramedia Pustaka Utama, 2006

Maryunani, Pembangunan Bumdes dan Pemerdayaan Pemerintah Desa, Bandung: Pustaka Setia, 2008

Muhammad, Abdulkadir, Hukum dan Penelitian Hukum, Bandung: Cita Aditya Bakti, 2004.

R. Ali Rido, Badan Hukum dan kedudukan Badan Hukum Perseroan, Perkumpulan, Koperasi, Yayasan dan Wakaf, Bandung: Alumni, 2004

Soedarsono Hadisapoetro, Badan Usaha Unit Desa dan Pembinaannya, dalam Pemikiran dan Permasalahan Ekonomi Indonesia Setengah Abad Terakhir: Buku 3 (1966-1982) Paruh Pertama Ekonomi Orde Baru, Yogyakarta, Kanisius, 2005

Sugiayanto, Urgensi dan Kemandirian Desa dalam Presfektif Undang-Undang No 6 Tahun 2014, Yogyakarta:
Deepublish, 2017

Surakhmad,

Winarno, Pengantar

Penelitian Ilmiah: Dasar dan

Teknik, Bandung: Tarsito, 1985

Tandelin, Eduardus, Analisis Investasi dan Manajemen Portfolio, Edisi Pertama, Yogyakarta: BPFE, 2001

Widjaja, H. AW, Pemerintahan Desa dan Administrasi Desa Menurut UndangUndang Nomor 5 Tahun 1979, Jakarta: Raja Grafindo Persada, 2002

Widjaja, HAW, Pemerintahan Desa/Marga. Jakarta: Raja Grafindo Persada, 2003

\section{Jurnal dan Artikel}

Detik News, "Tingkatkan Perekonomian Desa, 74 Ribu Desa Bakal Terima Dana Rp 1,4 Miliar”, www.news.detik.com diakses pada 6 Januari 2016

Harian Kompas, "Jumlah BUMDes Mencapai 18.446 Unit”, www.ekonomi.kompas.com diakses pada 4 April 2017

Harian Republika, "Urusan Desa Tumpang Tindih Kewenangan", www.m.republika.co.id diakses 6 Januari 2016.

\section{Peraturan Perundang-Undangan}

Undang-Undang Nomor 40 Tahun 2007 tentang Perseroan Terbatas

Undang-Undang Nomor 6 Tahun 2014 tentang Desa

Peraturan Menteri Desa, PDT dan Transmigrasi Nomor 4 Tahun 2015 Tentang BUMDes 